\title{
Screening of Potential Inhibitors of Covid-19 with Repurposing Approach Via Molecular Docking
}

\section{Negin Alizadehmohajer}

Islamic azad university, Kermanshah

\section{Bahman Sadeghi}

Arak University of Medical Sciences

\section{Simin Najafgholian}

Arak university of medical sciences

\section{Shabnam Moradi}

Shiraz University

\section{Forogh Mohammadi}

Islamic azad university. kermanshah

Reza Nedaeinia ( $\sim$ molecular_biology@mail.mui.ac.ir)

Isfahan University of Medical Sciences https://orcid.org/0000-0001-9922-7181

Shaghayegh haghjooy javanmard

Isfahan university of medical sciences

Ehsan Sohrabi

Iran university of medical sciences

\section{Rasoul Salehi}

Isfahan University of Medical Sciences

\section{Gordon A.Ferns}

Brighton and Sussex Medical School

\section{Mostafa Manian}

Iran University of Medical Sciences: Tehran University of Medical Sciences

\section{Asieh Emami Nejad}

payame noor university

\section{Research}

Keywords: COVID-19, Abl kinase inhibitors, Janus kinase inhibitor, Dipeptidyl peptidase 4 inhibitors, RNAdependent RNA polymerase inhibitors, Papin-like Protease inhibitors

Posted Date: October 21st, 2020

DOI: https://doi.org/10.21203/rs.3.rs-94371/v1 
License: (c) (i) This work is licensed under a Creative Commons Attribution 4.0 International License. Read Full License

Version of Record: A version of this preprint was published at Network Modeling Analysis in Health Informatics and Bioinformatics on February 4th, 2022. See the published version at https://doi.org/10.1007/s13721-021-00341-3. 


\section{Abstract}

Background: 2019-nCoV (COVID-19) is a pandemic disease with a high infectivity and mortality. The prevention and treatment of COVID-19 have become urgent matters for consideration. It often takes several years to develop new drugs, or vaccines, based on the usual clinical trial process. This dwell-time can be shortened by repurposing previously approved drugs.

Methods: We have designed and evaluated a bacterial biosensor expressing a luciferase We aimed to assess several available small-molecule; Abl kinase inhibitors, Janus kinase inhibitor, Dipeptidyl peptidase 4 inhibitors, RNA-dependent RNA polymerase inhibitors, and Papin-like Protease inhibitors, using binding simulation with proteins that might prove to be effective in inhibiting COVID-19 infection. The efficiency of inhibitors was evaluated based on docking scores using auto dock vina software.

Results: Strong ligand-protein interactions were predicted among some of these drugs, such as Imatinib, Remdesivir, and Telaprevir, and this may render these compounds promising candidates. Some candidate drugs might be efficient in disease control (directly and indirectly) or in viral proteins attenuation. It is worth to highlight the powerful immunomodulatory role of Abivertinib that inhibits pro-inflammatory cytokine production that are associated with cytokine release syndrome (CRS) or cytokine storm and progression of COVID-19 infection.

Conclusions: COVID-19 is similar to SARS-CoV, the potential role of Abl kinase inhibitors such as Imatinib in reducing SARS-CoV and MERS-CoV viral titers, immune regulatory function and the development of acute respiratory distress syndrome (ARDS) may indicate that these drugs may be useful for COVID-19. Moreover, Remdesivir, and Telaprevir have the most efficiency with their docked proteins in-silico as well although clinical trials are needed to confirm the effect of these drugs.

\section{Background}

Coronaviruses are enveloped RNA viruses that include those causing severe acute respiratory syndrome coronavirus (SARS-CoV) and Middle East respiratory syndrome coronavirus (MERS-CoV). SARS-CoV- 2 is a novel coronavirus that causes a respiratory illness and that has now been declared a pandemic, having been first identified in Wuhan, China, in December 2019 [1, 2]. COVID-19 has two categories of proteins; structural proteins that include: Spike (S) that characterize all coronaviruses, Nucleocapsid (N), Matrix $(\mathrm{M})$, and Envelope (E); and non-structural proteins, that include: proteases (nsp3 and nsp5) and RdRp (nsp12) [3]. An essential step for replication of the enveloped viruses such as coronaviruses, is to enter the host cells by fusing with cell membranes[4]. The virus attaches and enters the host cells in the respiratory tract using the spike protein [3]. It has also been shown that SARS-CoV-2 can infect T cells through a receptor-dependent, S protein-mediated membrane fusion [5]. COVID-19 infection may be associated with lymphopenia and occasionally the release of very high levels of inflammatory cytokines that has been described as a "cytokine storm." The latter has a major role in the development of inflammation-induced lung injury, that can lead to acute respiratory distress syndrome (ARDS), respiratory failure, and death [4, 6]. Symptoms of COVID-19 include: dry cough, fever, breathing difficulties, headache, pneumonia [7], new 
loss of taste or smell, nausea or vomiting and diarrhea [8]. An increased total neutrophil count and decreased total lymphocytes are related to disease severity and risk of mortality [9]. There is currently no specific medication for COVID-19 available, so neutralizing monoclonal antibody-based therapeutics and small-molecules are being evaluated to combat COVID-19 [10]. There are three key drug target strategies for SARS-CoV-2: 1. Block entry of the virus to the host, 2. Host's undirected inflammatory response reduction 3 . Block replication within the host $[11,12]$. Moreover, there are many factors that might contribute in viral infection through different mechanisms of action directly or indirectly, including Abl kinase, Janus kinase, Dipeptidyl peptidase 4, RNA-dependent RNA polymerase, viral main protease and Papin-like Protease, which will be discussed further. Repurposing FDA-approved drugs creates opportunities to advance potential new treatments for COVID-19 especially for patients who are suffering from severe disease; for example, there is the possibility that some drugs such as Imatinib can be repurposed [13]. Other drugs are being evaluated in clinical trials, such as Abelson (Abl) kinase inhibitors (Imatinib), anti-malarials, RNA-dependent RNA polymerase (RdRP) inhibitors, and Papin-like Protease Inhibitors. The ClinicalTrials.gov Web site describes the candidate drugs currently being tested for COVID19 prevention and/or treatment (Table 1). In silico evaluation of the possible viral inhibitory effectiveness of small molcules can be assessed by ligand-binding simulations. Therefore, the aim of this study was to evaluate the efficiency of candidate drugs and binding affinity with structural component of SARS-CoV-2, particularly in the contest of small-molecule inhibitors; Abl kinase inhibitors (Imatinib), Janus kinase inhibitor, Dipeptidyl peptidase 4 inhibitors, RdRP inhibitors, and Papin-like Protease inhibitors using insilico simulations by auto dock vina software. 
Table 1

Clinical trials related to the coronavirus disease 2019-nCoV and candidate drugs

\begin{tabular}{|c|c|c|c|c|c|}
\hline $\begin{array}{l}\text { ClinicalTrials.gov } \\
\text { identifier }\end{array}$ & Drug class & Drug name & $\begin{array}{l}\text { Estimated } \\
\text { enrollment }\end{array}$ & aim & $\begin{array}{l}\text { Primary } \\
\text { purpose }\end{array}$ \\
\hline NCT04356495 & $\begin{array}{l}\begin{array}{l}\text { Abl kinase } \\
\text { inhibitor, }\end{array} \\
\begin{array}{l}\text { Anti- } \\
\text { malaria, }\end{array} \\
\text { RdRps } \\
\text { inhibitor, } \\
\text { Angiotensin } \\
\text { receptor } \\
\text { blocker } \\
\text { (ARB) }\end{array}$ & $\begin{array}{l}\text { Imatinib, } \\
\text { Hydroxychloroquine, } \\
\text { Favipiravir, } \\
\text { Telmisartan }\end{array}$ & $\begin{array}{l}1057 \\
\text { participants }\end{array}$ & $\begin{array}{l}\text { estimate the } \\
\text { efficacy and } \\
\text { tolerance of } \\
\text { the } \\
\text { experimental } \\
\text { treatments }\end{array}$ & Treatment \\
\hline NCT04357613 & $\begin{array}{l}\text { Abl kinase } \\
\text { inhibitor }\end{array}$ & Imatinib & $\begin{array}{l}99 \\
\text { participants }\end{array}$ & $\begin{array}{l}\text { Test the } \\
\text { value of } \\
\text { Imatinib as } \\
\text { an early } \\
\text { treatment of } \\
\text { COVID-19 }\end{array}$ & Treatment \\
\hline NCT04330300 & $\begin{array}{l}\text { ACE } \\
\text { inhibitor, } \\
\text { Angiotensin } \\
\text { receptor } \\
\text { blocker }\end{array}$ & $\begin{array}{l}\text { Benazepril, } \\
\text { Captopril, Enalapril, } \\
\text { Fosinopril, lisinopril, } \\
\text { Perindopril, } \\
\text { Quinapril, Ramipril, } \\
\text { Trandolapril }\end{array}$ & $\begin{array}{l}2414 \\
\text { participants }\end{array}$ & $\begin{array}{l}\text { CORONA } \\
\text { virus } \\
\text { Angiotensin } \\
\text { Converting } \\
\text { Enzyme } \\
\text { Inhibitors, } \\
\text { Angiotensin } \\
\text { Receptor } \\
\text { Blockers } \\
\text { Investigation }\end{array}$ & Prevention \\
\hline NCT04257656 & $\begin{array}{l}\text { RdRps } \\
\text { inhibitor }\end{array}$ & Remdesivir & $\begin{array}{l}453 \\
\text { participants }\end{array}$ & $\begin{array}{l}\text { Evaluate the } \\
\text { Efficacy and } \\
\text { Safety of } \\
\text { Remdesivir }\end{array}$ & Treatment \\
\hline NCT04280705 & $\begin{array}{l}\text { RdRps } \\
\text { inhibitor }\end{array}$ & Remdesivir & $\begin{array}{l}1062 \\
\text { participants }\end{array}$ & $\begin{array}{l}\text { Evaluate the } \\
\text { Efficacy and } \\
\text { Safety of } \\
\text { Remdesivir } \\
\text { (Phase 3) }\end{array}$ & Treatment \\
\hline NCT04276688 & $\begin{array}{l}\text { RdRps } \\
\text { inhibitor, } \\
\text { 3CLpro } \\
\text { inhibitor }\end{array}$ & $\begin{array}{l}\text { Ribavirin, Lopinavir, } \\
\text { Ritonavir }\end{array}$ & $\begin{array}{l}70 \\
\text { participants }\end{array}$ & $\begin{array}{l}\text { Investigate a } \\
\text { combination } \\
\text { of lopinavir, } \\
\text { Ritonavir, } \\
\text { Ribavirin } \\
\text { and } \\
\text { interferon } \\
\text { beta-1b }\end{array}$ & Treatment \\
\hline
\end{tabular}




\begin{tabular}{|c|c|c|c|c|c|}
\hline $\begin{array}{l}\text { ClinicalTrials.gov } \\
\text { identifier }\end{array}$ & Drug class & Drug name & $\begin{array}{l}\text { Estimated } \\
\text { enrollment }\end{array}$ & aim & $\begin{array}{l}\text { Primary } \\
\text { purpose }\end{array}$ \\
\hline NCT04310228 & $\begin{array}{l}\text { RdRps } \\
\text { inhibitor, } \\
\text { Interleukin- } \\
6 \text { (IL-6) } \\
\text { blockers }\end{array}$ & $\begin{array}{l}\text { Favipiravir, } \\
\text { Tocilizumab }\end{array}$ & $\begin{array}{l}150 \\
\text { participants }\end{array}$ & $\begin{array}{l}\text { evaluate the } \\
\text { efficacy and } \\
\text { safety of } \\
\text { Favipiravir } \\
\text { combined } \\
\text { with } \\
\text { Tocilizumab }\end{array}$ & Treatment \\
\hline NCT04307693 & $\begin{array}{l}3 \mathrm{CL} \\
\text { protease } \\
\text { inhibitor }\end{array}$ & Lopinavir, Ritonavir & $\begin{array}{l}150 \\
\text { participants }\end{array}$ & $\begin{array}{l}\text { investigate } \\
\text { Lopinavir, } \\
\text { Ritonavir in } \\
\text { Patients } \\
\text { With Mild } \\
\text { Coronavirus } \\
\text { Disease }\end{array}$ & Treatment \\
\hline NCT04440007 & $\begin{array}{l}\text { EGFR } \\
\text { tyrosine } \\
\text { kinase } \\
\text { inhibitor } \\
\text { and BTK } \\
\text { Inhibitor }\end{array}$ & Abivertinib & $\begin{array}{l}80 \\
\text { participants }\end{array}$ & $\begin{array}{l}\text { A Phase } 2 \\
\text { Randomized } \\
\text { Study of the } \\
\text { Efficacy and } \\
\text { Safety of } \\
\text { Abivertinib } \\
\text { Maleate in } \\
\text { Hospitalized } \\
\text { patients } \\
\text { With COVID- } \\
19\end{array}$ & Treatment \\
\hline
\end{tabular}

\section{Results And Discussion}

In the present study, based on the importance of inhibition in reducing or stopping the activity of COVID19- ligand with the ability to inhibit the virus in the drug database has been used. For this purpose, and considering the importance of identifying ligand-receptor interactions, the effectiveness of each of these ligands on the related proteins has been evaluated during the molecular docking simulation process.

\section{Abl kinase inhibitors}

$\mathrm{Abl}$ kinases are non-receptor tyrosine kinases that are involved in various cellular processes, especially as mediators of viral infection and/or may be involved in T-cell signaling [14]. Imatinib is an Abl kinase inhibitor used to treat Philadelphia chromosome-positive chronic myelogenous leukemia (CML) and acute lymphocytic leukemia (ALL). This small-molecule inhibitor works by inhibiting Bcr-Ab/tyrosine-kinase [15]. It has been shown, from previous studies, that an Abelson (Abl) kinase inhibitor, Imatinib, substantially decreases SARS-COV and MERS-CoV viral titers. In the same study, they also investigated the bronchitis virus (IBV) to study the function of Abl kinase activity during coronavirus infection and found that Imatinib and two different Abl kinase inhibitors, GNF2 and GNF5, reduced IBV titers by blocking virus infection [1]. Previously, Imatinib was shown to block the entry of SARS-CoV or MERS-CoV S protein [1]. 
SARS-CoV-2 is highly homologous to SARS-CoV, so studying the effects of Abl kinase inhibitors on IBV, SARS-CoV and MERS-CoV may be useful in identifying the host cell pathways required for COVID-19 infection. It may also provide insights into potential strategies for the treatment of COVID-19 especially by using Imatinib. Virus-cell and cell-cell fusion induced by the coronavirus $S$ protein has a very similar mechanism. Abl kinase activity plays a role in cytoskeletal rearrangement, regulating endothelial barrier, and junctional dynamics, and hence Abl kinase inhibitors might also be capable of interacting by interfering with the actin dynamics needed for virus - cell and cell - cell fusion in SARA-CoV-2. Furthermore, studies have indicated that Abl kinase regulates inflammatory signaling, NFKB signaling, and oxidant-induced epithelial cells injury caused by infection and ARDS which can be followed by COVID-19 $[1,16]$. In epithelial cell injury $\mathrm{H}_{2} \mathrm{O}_{2}$ release leads to C-Abl activation and nuclear translocation. C-Abl inhibition by Imatinib increases the expression of antioxidant proteins such as catalase and glutathione peroxidase, which have been reduced due to oxidative stress. Therefore, treatment with Imatinib during ARDS may prevent the death of lung cells [16]. Coleman et al., investigated the Abl kinase inhibitors, including Imatinib, in SARS-CoV and MERS-CoV in vitro. In the early stages of infection, after internalization and endosomal trafficking, the anti-CoV activity of Imatinib is effected by inhibiting virion fusion in the endosomal membrane. Imatinib inhibits a step in virion replication before the genomic production of RNA. They also investigated the role of $\mathrm{Abl}_{2}$ in the replication of SARS-CoV and MERS-CoV. To knock down the $\mathrm{Abl}_{2}$ protein levels, siRNA was used. They demonstrated that $\mathrm{Abl}_{2}$ expression is essential for a productive viral replication and can be blocked by Imatinib [17]. Imatinib and its methane sulfonate derivative can be used in treating viral liver diseases, in particular viral hepatitis by inhibiting replication, transmission, or both, of hepatitis viruses or of other RNA viruses including respiratory syncytial virus, herpes virus, influenza virus, poxvirus, para influenza virus, rhinovirus, yellow fever virus, West Nile virus, and encephalitis virus in order to maintain or decrease RNA viral load. Although it is not meant to be limited to any particular mechanism of action or bound by definition, it is suspected that Imatinib's antiviral properties may be partly due to its ability to inhibit viral replication and transmission. Cellular signal transduction pathways are known to play an important role in viral infection, and cellular phosphorylation events during viral infection so they are required to effectively replicate and proliferate the virus. Several cellular signaling pathways, related to viral replication, have been investigated. Tyrosine kinase inhibitors can be used, for example, epidermal receptor growth factor (EGFR) inhibitors such as monoclonal antibodies and small-molecule inhibitors. EGFR inhibitors including monoclonal antibodies, such as IMC-C225 (Cetuximab), Trastuzumab (Herceptin), and others (ABX-EGF, EMD 72000), and tyrosine-kinase inhibitors, such as OSI-774 (Erlotinib, Tarceva), ZD1839 (Gefitinib, Iressa), and others (GW2016, Cl-1033), can be used in combination therapy with Imatinib. Monoclonal antibodies can block extracellular ligand binding, but at the intracellular portion of the receptor, the small-molecule inhibitors may exert their effects to prevent tyrosine kinase phosphorylation and the activation of signal transduction pathways [18]. Consequently, combination therapy may be useful in COVID-19 treatment as well as for the other RNA viruses. According to the Hubei Anti-Cancer Association Chronic Myeloid Leukemia Standardized Management Collaboration Group research on 299 CML patients who responded optimally to anti-CML therapy using Imatinib and other tyrosine kinase inhibitors, $0.3 \%$ of patients were infected by SARS-CoV-2 and among those who failed to respond to CML treatment, $2 \%$ of patients were 
diagnosed with COVID-19. Therefore, patients who failed to receive an appropriate response to anti-CML therapy medications were more likely to get infected by SARS-CoV-2. Although more detailed clinical data and studies on the prevalence of COVID-19 in patients with CML is required, this idea may be consistent with several possibilities [19]. For instance, it has been shown that the total number of natural killer (NK) cells and Regulatory T cells was decreased markedly in patients with CML as well as COVID-19 infection $[20,21]$ while tyrosine kinase inhibitors are able to regulate the immune system by increasing the number of natural killer cells (NK) and Regulatory T cells [19]. In order to assess the potential effectiveness of Imatinib on COVID-19, by using molecular docking, we investigated the affinity and efficiency of Imatinib and possible intermediary proteins: Spike protein and RNA-dependent RNA polymerases (RdRps).According to the NCBI database and Basic Local Alignment Search Tool (BLAST), we found that SARS-CoV-2 spike protein (PDB: 6XR8) and SARS-CoV spike protein (PDB: $5 \times 58$ ) Query Cover is 76.16\% with a GMQE of 0.80 , which makes it promising to consider the proteins similar. The docking results are shown in Table 2; low energy indicates the optimum protein-ligand complexes. Accordingly, docking scores for SARS-CoV-2 and SARS CoV were -9.6 and $-10.2 \mathrm{kcal} / \mathrm{mol}$ respectively which are low enough to show the appropriate protein-ligand complexes. Docking interactions of Imatinib based on docking studies are depicted in Fig. 1. Furthermore, the type of interaction with the number of active site amino acids is also considered effective. In terms of interactions, the presence of hydrogen bond interactions can be very important as they have critical contributions to the binding structures and binding free energies, although the van der Waals and Pi-interactions contributed to the stabilization of the binding structures. If these interactions take place in the active position of proteins, it will be much better and more desirable. Interaction Types and Amino Acids involved in the inhibition of proteins are shown in Table 6.

Table 2

The docking score of Imatinib to SARS-CoV-2 and SARS-CoV spike protein, SARS-CoV-2 RNA- dependent RNA polymerases (RdRps) (RMSD: 0.00)

\begin{tabular}{|lllllll|}
\hline $\begin{array}{l}\text { Drug } \\
\text { name }\end{array}$ & $\begin{array}{l}\text { Drug } \\
\text { bank ID }\end{array}$ & $\begin{array}{l}\text { 2D } \\
\text { structure }\end{array}$ & $\begin{array}{l}\text { Drug } \\
\text { use }\end{array}$ & $\begin{array}{l}\text { Binding } \\
\text { affinity (total } \\
\text { energy): } \\
\text { SARS-CoV-2 } \\
\text { spike protein }\end{array}$ & $\begin{array}{l}\text { Binding } \\
\text { affinity (total } \\
\text { energy): } \\
\text { SARS-CoV } \\
\text { spike protein }\end{array}$ & $\begin{array}{l}\text { Binding affinity (total } \\
\text { energy): SARS-CoV-2 } \\
\text { RNA-dependent RNA } \\
\text { polymerases (RdRps) }\end{array}$ \\
\hline Imatinib & DB00619 & & $\begin{array}{l}\text { Anti- } \\
\text { cancer }\end{array}$ & -9.6 & -10.2 & -8.1 \\
\hline
\end{tabular}

Binding interactions of Imatinib and SARS-CoV-2 spike protein shows that Imatinib interacts by forming Hydrogen bond with residue SER B: 50 and SER B: 967 . A pi-sigma interaction is also visible between the drug and amino acid THR B: 302 and Pi-Alkyl interactions with LEU C: 754 and CYS C: 760 . The large number of Pi-sigma interactions which involves charge transfer and helps in intercalating the drug in the binding site of the receptor. Pi-alkyl bond also improves the hydrophobic interactions of the ligand in the binding pocket of the receptor. With regards to the van der Waals interactions, it should be mentioned that there are thirteen amino acids contributing with the ligand, including: LYS B: 304, HIS B: 49, ASN C: 764, 
CYS C: 738, ASP C: 737, VAL C: 736, SER C: 735, THR B: 315, GLN B: 314, SER B: 316, ARG B: 319, THR B: 274 and GLY C: 757. Also, Imatinib inhibits SARS-CoV-2 with an IC50 of $130 \mathrm{nM}$. But, although imatinib binds to the receptor-binding domain (RBD) of SARS-CoV-2 spike protein, it does not inhibit the spike RBD: ACE2 interaction, suggesting a Bcr-Abl kinase-mediated fusion inhibition mechanism is responsible for the inhibitory action [22]. Another small molecule tyrosine kinase inhibitor (TKI) is Abivertinib used in lung cancer treatment, targeting both mutant forms of the epidermal growth factor receptor (EGFR) and Bruton's tyrosine kinase (BTK). Abivertinib binds to the BTK receptor which results in receptor phosphorylation prevention. It also plays a powerful immunomodulatory role in vitro by inhibiting proinflammatory cytokine production that are associated with cytokine release syndrome (CRS) or cytokine storm and progression of COVID-19 infection such as IL-1beta, IL-6 and TNF-alpha in patients with acute respiratory distress syndrome (ARDS). It is worth noting that FDA clears Abivertinib for Phase 2 safety and efficacy study in hospitalized patients with moderateto severe COVID-19

(http://www.aceatherapeutics.com). This strongly indicates that the Abl kinase signaling pathway is a promising area to study for the development of antiviral therapies.

\section{Janus Kinase Inhibitor (jak Inhibitor)}

Janus kinase inhibitors are being used in cancer treatment and inflammatory diseases by inhibiting the activity of the Janus kinase family of enzymes (JAK1, JAK2, JAK3, TYK2), by interfering with the JAKSTAT signaling pathway [23]. Ruxolitinib is one of those inhibitors with an anti-inflammatory effect related to the inhibition of the release of cytokines. This drug is used for the treatment of myelofibrosis and polycythemia vera (PCV) [24]. Also, Ruxolitinib has been approved in Covid-19 patients with respiratory failure with no invasive assisted ventilation required [25]. Improvement in chest computed tomography and faster recovery from lymphopenia were seen in patients as well [26]. Another JAK inhibitor is Baricitinib used for rheumatoid arthritis. A randomized phase 2 trial for this drug has been licensed to the usual treatment of pneumonia in COVID-19 patients [25]. Transcription by interferonactivated JAK - STAT signaling pathway (mainly mediated by JAK1 and JAK2) contributes to the upregulation of several interferon-controlled genes which destroy viruses in infected cells rapidly. Many viruses have formed strategies to combat interferon effects by blocking their signaling pathways, and viral-encoded factors that antagonize the JAK - STAT pathway are important virulence determinants. So, baricitinib blocking of the JAK - STAT signal results in interferon-mediated antiviral response inhibition that has an impact on SARS-CoV-2 infection progression [27]. According to another cohort study, baricitinib in combination with remdesivir and hydroxychloroquine showed clinical improvement in patients [28]. Moreover, docking results between SARS-CoV-2 main protease and our two JAK inhibitors (Ruxolitinib and baricitinib) were -6.2 and $-6.1 \mathrm{kcal} / \mathrm{mol}$ respectively (Table 3 ). 
Table 3

The docking score of candidate inhibitors to SARS-CoV-2 main protease and SARS-CoV-2 spike protein.

\begin{tabular}{|llllll|}
\hline $\begin{array}{l}\text { Drug } \\
\text { name }\end{array}$ & $\begin{array}{l}\text { Drug } \\
\text { bank } \\
\text { ID }\end{array}$ & $\begin{array}{l}\text { 2D } \\
\text { structure }\end{array}$ & Protein target & Drug use & $\begin{array}{c}\text { Binding affinity } \\
\text { (total energy) }\end{array}$ \\
\hline Ruxolitinib & DB08877 & $\begin{array}{l}\text { SARS-CoV-2 } \\
\text { main protease }\end{array}$ & $\begin{array}{l}\text { treatment of intermediate or } \\
\text { high-risk myelofibrosis }\end{array}$ & -6.2 \\
\hline baricitinib & DB11817 & $\begin{array}{l}\text { SARS-CoV-2 } \\
\text { main protease }\end{array}$ & $\begin{array}{l}\text { treatment of rheumatoid } \\
\text { arthritis (RA) }\end{array}$ & -6.1 \\
\hline Sitagliptin & DB01261 & $\begin{array}{l}\text { SARS-CoV-2 } \\
\text { spike protein }\end{array}$ & $\begin{array}{l}\text { Treatment of diabetes } \\
\text { mellitus type 2 }\end{array}$ & -6.0 \\
\hline
\end{tabular}

\section{Dipeptidyl Peptidase 4 Inhibitors (dpp4i)}

Besides the main viral entrance port, angiotensin converting enzyme 2 (ACE2), dipeptidyl peptidase 4 (DPP4) can be investigated as well. DPP4 is a type II trans membrane glycoprotein with its major role in glucose and insulin metabolism which is expressed in many tissues, such as the immune cells. Also, it plays a significant role in immune regulation by activating Tcells, modulating NF-jB pathway, and the expression of CD86. Dipeptidyl peptidase 4 inhibitors mainly Sitagliptin can be used to treat diabetes mellitus type 2. Moreover, it was identified as a functional receptor for the MERS-CoV spike protein and although SARS-CoV-2 spike protein does not necessarily need DPP4. In spite of Sitagliptin and SARS-CoV2 spike protein docking result with the score of $-6.0 \mathrm{kcal} / \mathrm{mol}$ and the possibility that it does not alter ACE2, the potential anti-inflammatory involvement of DPP4 inhibitors raises concerns about DPP4 modulation that might decrease the cytokine-mediated acute respiratory complications of COVID-19 infection $[25,29]$ (Table 3) .

\section{Rna-dependent Rna Polymerase Inhibitors}

RNA-dependent RNA polymerase (RdRP) is an enzyme that catalyzes the replication of RNA from an RNA template which is encoded in the genomes of all RNA viruses [30] including SARS-CoV-2. There are some drugs that are considered to be nucleotide analog inhibitors of RdRps. Remdesivir (RDV) is one of those investigational drugs that have a wide variety of antiviral activities against RNA viruses including coronaviruses [31]. Remdesivir suppresses viral replication and it was initially tested in clinical trials to prevent the 2014 Ebola outbreak. Later investigations indicated Remdesivir's ability to inhibit replication of coronavirus, including SARS-CoV-2 as well [32]. In another cohort study, medical progress was observed in $68 \%$ of patients taken to the hospital with severe COVID-19 treated with Remdesivir [33]. In Japan also Favipiravir, an antiviral drug that targets the influenza viral RNA-dependent RNA polymerase, has been used against SARS-Cov-2 [34]. Ribavirin and Galidesivir [3] are other recommended drugs that 
we studied using auto dock vina. Accordingly, Remdesivir (Fig. 1) has the best binding capability with the score of $-9.0 \mathrm{kcal} / \mathrm{mol}$. From our docking studies, with the better binding energy compounds, the identified active residues were Lys47, Ser784, Ser709, Tyr129, His133 and Thr141. The major interaction between Remdesivir and RdRP is characterized by hydrogen bonding between the oxygen with TYR A: 129. A PiCation interaction of aromatic ring and LYS A: 780 and an Alkyl interaction with ALA A: 706 have been observed. The docked result of the displayed in Fig. 1 indicates the drugs has eight hydrogen bond interaction with six amino acids reported on Table 6. Other important interactions such as alkyl, Pi-Cation interactions were also reported Table 6 . Remdesivir high affinity has also been correlated with the existence of Van der waal forces formed on the amide substituents backbone with the respective amino acids GLY A: 774,ASP A:135, ALA A: 46. THR A: 710, LYS A: 714, GLN A: 773, ASN A: 705 AND SER A: 784, which established a strong cohesive environment, thus stabilizing the formed complex. It exhibits effective in vitro activity against SARS-CoV-2 with an $\mathrm{EC}_{50}$ at $48 \mathrm{~h}$ of $0.77 \mu \mathrm{M}$ in Vero E6 cells [5]. On the other hand, Favipiravir had the least affinity to RdRps despite the recorded efficiency based on clinical trials (Table 4).

Table 4

The docking score of candidate inhibitors to COVID-19 RNA-dependent RNA polymerases (RdRps)

\begin{tabular}{|c|c|c|c|c|}
\hline Drug name & Drug bank ID & 2D structure & Drug use & Binding affinity (total energy) \\
\hline Remdesivir & DB14761 & & Antiviral & -9.0 \\
\hline Galidesivir & DB11676 & & Antiviral & -6.9 \\
\hline Ribavirin & DB00811 & & Antiviral & -6.3 \\
\hline Favipiravir & DB12466 & & Antiviral & -5.4 \\
\hline
\end{tabular}

\section{Papain-like Protease Inhibitors}

Papain-like Protease (PLpro) is characterized in different coronaviruses, including SARS and MERS [35]. Also, the genome of SARS-CoV-2 encodes for different proteins including PLpro[36]. The SARS-CoV PLpro and SARS-CoV-2 PLpro protein sequences are similar, so protease inhibitors that have shown efficacy against SARS-CoV might be similarly effective against SARS-CoV-2. Papain-like protease (PLpro) has a crucial role in the viral life-cycle $[37,38]$. Targeting PLpro with antiviral drugs may result in viral replication blockage and the deregulation of signaling cascades in infected cells inhibition [39]. Consequently, antiHCV drugs (Telaprevir, Grazoprevir, and Boceprevir) that bind to the SARS-CoV-2 PLpro active site (contained residues Asp164, Val165, Arg166, Glu167, Met 208, Ala246, Pro247, Pro248, Tyr 264, Gly266, Asn267, Tyr 268, GIn269, Cys217, Gly271, Tyr273, Thr301 and Asp302), may therefore oppose viral replication [35, 40]. Similarly, our study showed that Telaprevir (Fig. 1), Grazoprevir, and Boceprevir (HCV protease inhibitor) may be effective in binding to SARS-CoV-2 papain-like protease (PLpro) active sites to prevent viral replication (Table 5)[41]. Regarding to the lowest binding energy, the best ligand was 
Telaprevir with the score of $-9.9 \mathrm{kcal} / \mathrm{mol}$. The results of docking analysis (Table 6) showed that Telaprevir forms Hydrogen bonds with the 6W9C amino acids LYS B:92, HIS B:89 and THR A:74. Also there can be seen that the ligand interacts with LYS B: 92 via Pi-Cation and TYR A: 171 and ILE B: 44 via Pi-Alkyl interactions.

Table 5

The docking score of candidate HCV protease inhibitors to SARS-CoV-2 Papain-like protease (PLpro)

\begin{tabular}{|lllll|}
\hline Drug name & Drug bank ID & 2D structure & Drug use & Binding affinity (total energy) \\
\hline Telaprevir & DB05521 & Anti-Hepatitis C & -9.9 \\
\hline Grazoprevir & DB11575 & Anti-Hepatitis C & -8.7 \\
\hline Boceprevir & DB08873 & Anti-Hepatitis C & -7.8 \\
\hline
\end{tabular}

Table 6

Interaction types and Amino acids involved in the Inhibition of PDB: 6XR8, PDB: 6M71

\begin{tabular}{|c|c|c|c|c|c|c|}
\hline Ligand & Protein & $\begin{array}{l}\text { Conventional } \\
\text { Hydrogen } \\
\text { Bond }\end{array}$ & $\begin{array}{l}\text { Carbon } \\
\text { hydrogen } \\
\text { bond }\end{array}$ & $\begin{array}{l}\text { Pi-sigma and } \\
\text { amide } \\
\text { interaction }\end{array}$ & $\begin{array}{l}\text { Alkyl } \\
\text { Interaction }\end{array}$ & $\begin{array}{l}\text { Pi- Cation } \\
\text { interactior }\end{array}$ \\
\hline \multirow[t]{2}{*}{ Imatinib } & \multirow{2}{*}{$\begin{array}{l}\text { PDB: } \\
\text { 6XR8 }\end{array}$} & SER B:50 & \multirow[t]{2}{*}{ THR C: 761} & \multirow[t]{2}{*}{ THR B: 302} & $\begin{array}{l}\text { CYS C: } \\
760\end{array}$ & \multirow[t]{2}{*}{-} \\
\hline & & SER B: 967 & & & $\begin{array}{l}\text { LEU C: } \\
754\end{array}$ & \\
\hline \multirow[t]{6}{*}{ Remdesivir } & \multirow{6}{*}{$\begin{array}{l}\text { PDB: } \\
\text { 6M71 }\end{array}$} & ASN A: 781 & \multirow[t]{6}{*}{ SER A: 709} & \multirow[t]{6}{*}{ - } & \multirow{6}{*}{$\begin{array}{l}\text { ALA A: } \\
706\end{array}$} & \multirow{6}{*}{$\begin{array}{l}\text { LYS A: } \\
780\end{array}$} \\
\hline & & HIS A: 133 & & & & \\
\hline & & SER A: 709 & & & & \\
\hline & & TYR A: 129 & & & & \\
\hline & & LYS A: 47 & & & & \\
\hline & & ASP A: 711 & & & & \\
\hline \multirow[t]{2}{*}{ Telaprevir } & \multirow{2}{*}{$\begin{array}{l}\text { PDB: } \\
\text { 6W9C }\end{array}$} & \multirow[t]{2}{*}{ LYS B: 92} & HIS B: 89 & \multirow[t]{2}{*}{-} & ILE B: 44 & \multirow[t]{2}{*}{ LYS B: 92} \\
\hline & & & THR A: 74 & & $\begin{array}{l}\text { TYR A: } \\
171\end{array}$ & \\
\hline
\end{tabular}




\section{Conclusion}

Our results show that the urgent need for a treatment for COVID-19 may be addressed by repurposing existing, approved pharmaceutical drugs. In this virtual drug repurposing study based on docking analysis, using established database for protein and ligand structures, we obtained the predicted binding scores of drugs. This will be important in evaluating the findings of continuing clinical trials testing small molecule drugs for efficacy against SARS-CoV-2 and the drugs different mechanisms of action. Imatinib plays roles in cytoskeletal rearrangement, inflammatory signaling, NK and Regulatory T cell modulation, and oxidant-induced epithelial cell injury followed by infection and ARDS which has been diagnosed among COVID-19 patients. Another TKI known as Abivertinib has an immunomodulatory function in patients with ARDS. Also, Remdesivir, and Telaprevir have the most efficiency with their docked proteins in-silico as well.

\section{Methods}

\section{Protein preparation}

For molecular docking, SARS-CoV-2 spike protein (PDB: 6XR8), SARS-CoV spike protein (PDB: $5 \times 58$ ), SARS-CoV-2 main protease (PDB:6LU7), RNA-dependent RNA polymerases (RdRps) (PDB: 6M71), and papain-like protease (PLpro) (PDB: 6W9C) were chosen to be the target proteins which were obtained from the RCSB (http://www.rscb.org) Protein Data Bank in PDB format. Due to the high number of reported structures, in the present study we used the complete structure, which had been previously studied in similar bioinformatics studies.

\section{Ligands Preparation}

Based on literature reviews, we tested 3D structures of the drugs, including: Imatinib (Abl kinase inhibitor), Ruxolitinib and Baricitinib (JAK inhibitors), Sitagliptin (Dipeptidyl peptidase 4 inhibitors), Remdesivir, Galidesivir, Ribavirin, Favipiravir (RdRps inhibitors), Telaprevir, Boceprevir, Grazoprevir (protease inhibitors) using Drug bank (https://www.drugbank.ca/) in Structure-data file (PDB) format. They also converted into (PDBQT) by AutoDock Tools software.

\section{Docking analysis}

To simulate protein and ligands binding affinity, molecular docking softwares (MVD) including AutoDock Tools (version 1.5.6) (http://autodock.scripps.edu) and AutoDock Vina (http://autodock.scripps.edu) were used. After that, the downloaded proteins inserted to the work place to be prepared. First, the water molecules were deleted and then, polar Hydrogen and kollman charges were added by the software tools. Autogrid then determinedthe native ligand position on the binding site by arranging the grid coordinates $(X, Y$, and $Z$ ). After the preparations, the bioactive conformations were simulated by AutoDock Vina. The exhaustiveness parameter that controls the extent of the search was chosen as 8 , and 9 models were 
generated for each ligand. According to the received results, lower energy scores demonstrate the best protein-ligand interacrions. A low binding affinity value of $10 \mu \mathrm{M}$ as a threshold to define a physical drugtarget interaction was used. The different poses of the ligands affect the estimation of the docking score, so the most active forms were used in order to obtain an accurate estimation. The interactions of amino acids and ligands were also examined by using Discovery Studio 4.5.

\section{Clinical Trials}

Clinical Trials data were downloaded from clinicaltrials.gov on 4th April 2020. Small molecule drugs used to prevent or treat COVID-19 were selected in interventional category (Table 1).

\section{Abbreviations}

ARDS

Acute respiratory distress syndrome; SARS-CoV:Severe acute respiratory syndrome coronavirus; MERSCoV; Middle East respiratory syndrome coronavirus; ACE:Angiotensin-converting enzyme; PDB:Protein Data Bank; PDBQT:Protein Data Bank, Partial Charge (Q), \& Atom Type (T); MVD:Molecular docking software; CML:Chronic myelogenous leukemia; ALL:Acute lymphocytic leukemia; TKl:tyrosine kinase inhibitor; EGFR:epidermal growth factor receptor; BTK:Bruton's tyrosine kinase; CRS:cytokine release syndrome; JAK inhibitor:Janus kinase inhibitor; ACE2:Angiotensin converting enzyme 2; AT2R:Angiotensin II receptor; DPP4i:Dipeptidyl peptidase 4 inhibitors; RdRP:RNA-dependent RNA polymerase; RDV:Remdesivir.

\section{Declarations}

\section{Acknowledgements}

Not applicable.

\section{Authors' contributions}

All authors were involved in method development. MM and RN designed research; NA wrote the manuscript; NA, BS, SN, FM and ES contributed equal time and effort in the investigation, research of the manuscript and designing of the figures. RS and GAF Revising the manuscript critically for important intellectual content. All authors read and approved the final manuscript.

\section{Funding}

Not applicable.

\section{Availability of data and materials}

Not applicable. 


\section{Ethics approval and consent to participate}

Not applicable.

\section{Consent for publication}

Not applicable.

\section{Declaration of Competing Interest}

The authors declare that they have no competing interests.

\section{Availability of data and material}

The data supporting the findings of this study are available within the article

\section{References}

1. Sisk JM, Frieman MB, Machamer CE. Coronavirus S protein-induced fusion is blocked prior to hemifusion by Abl kinase inhibitors. J Gen Virol. 2018;99(5):619.

2. Organization WH. Coronavirus disease 2019 (COVID-19): situation report, 45. 2020.

3. Ibrahim IM, et al. COVID-19 spike-host cell receptor GRP78 binding site prediction. J Infect. 2020;80(5):554-62.

4. Prompetchara E, Ketloy C, Palaga T. Immune responses in COVID-19 and potential vaccines: Lessons learned from SARS and MERS epidemic. Asian Pacific J. allergy Immunol, 2020. 10.

5. Wang $M$, et al. Remdesivir and chloroquine effectively inhibit the recently emerged novel coronavirus (2019-nCoV) in vitro. Cell research. 2020;30(3):269-71.

6. Chen C, et al., Advances in the research of cytokine storm mechanism induced by Corona Virus Disease 2019 and the corresponding immunotherapies. Zhonghua shao shang za zhi = Zhonghua shaoshang zazhi $=$ Chinese journal of burns, 2020. 36: p. E005.

7. Zhou P, et al. A pneumonia outbreak associated with a new coronavirus of probable bat origin. Nature. 2020;579(7798):270-3.

8. DeBiasi RL, et al., Severe COVID-19 in children and young adults in the Washington, DC metropolitan region. The Journal of pediatrics, 2020.

9. Sun M, et al. Inhibitors of RAS Might Be a Good Choice for the Therapy of COVID-19 Pneumonia. Zhonghua jie he he hu xi za zhi = Zhonghua jiehe he huxi zazhi = Chinese. journal of tuberculosis respiratory diseases. 2020;43:E014.

10. Choudhary S, et al., Identification of SARS-CoV-2 Cell Entry Inhibitors by Drug Repurposing Using in Silico Structure-Based Virtual Screening Approach. 2020, ChemRxiv.

11. Jakovac H. COVID-19: is the ACE2 just a foe? American Journal of Physiology-Lung Cellular and Molecular Physiology, 2020. 318(5): p. L1025-L1026. 
12. Quartuccio L, et al. Urgent avenues in the treatment of COVID-19: Targeting downstream inflammation to prevent catastrophic syndrome. Joint Bone Spine. 2020;87(3):191.

13. Shaw TD, McAuley DF, O'Kane CM. Emerging drugs for treating the acute respiratory distress syndrome. Expert Opinion on Emerging Drugs. 2019;24(1):29-41.

14. Khatri A, Wang J, Pendergast AM. Multifunctional Abl kinases in health and disease. J Cell Sci. 2016;129(1):9.

15. Kerkelä R, et al. Cardiotoxicity of the cancer therapeutic agent imatinib mesylate. Nature medicine. 2006;12(8):908-16.

16. Rizzo AN, et al., Targeting Abl kinases to regulate vascular leak during sepsis and acute respiratory distress syndrome. Arteriosclerosis, thrombosis, and vascular biology, 2015. 35(5): p. 1071-1079.

17. Coleman $\mathrm{CM}$, et al. Abelson kinase inhibitors are potent inhibitors of severe acute respiratory syndrome coronavirus and middle east respiratory syndrome coronavirus fusion. Journal of virology. 2016;90(19):8924-33.

18. Riviere P, Riviere M, Reader S, Use of imatinib to treat liver disorders and viral infections. 2012, Google Patents.

19. Wang D-Y, et al., The First Report of the Prevalence of COVID-19 in Chronic Myelogenous Leukemia Patients in the Core Epidemic Area of China: A Multicentre, Cross-Sectional Survey. 2020.

20. Zheng M, et al., Functional exhaustion of antiviral lymphocytes in COVID-19 patients. Cellular \& Molecular Immunology, 2020.

21. Qin C, et al., Dysregulation of Immune Response in Patients With Coronavirus 2019 (COVID-19) in Wuhan, China. Clinical Infectious Diseases, 2020.

22. Mulgaonkar N, et al., Bcr-Abl tyrosine kinase inhibitor imatinib as a potential drug for COVID-19. bioRxiv, 2020: p. 2020.06.18.158196.

23. Pesu M, et al. Therapeutic targeting of Janus kinases. Immunological reviews. 2008;223(1):132-42.

24. Mesa RA, Yasothan U, Kirkpatrick P. Ruxolitinib Nature Reviews Drug Discovery. 2012;11(2):103-4.

25. Di Lorenzo G, et al., COVID 19 therapies and anti-cancer drugs: A systematic review of recent literature. Critical Reviews in Oncology/Hematology, 2020: p. 102991.

26. Cao Y, et al. Ruxolitinib in treatment of severe coronavirus disease 2019 (COVID-19): A multicenter, single-blind, randomized controlled trial. Journal of Allergy Clinical Immunology. 2020;146(1):13746.e3.

27. Favalli EG, et al., Baricitinib for COVID-19: a suitable treatment? The Lancet Infectious Diseases, 2020.

28. Titanji BK, et al., Use of Baricitinib in Patients with Moderate and Severe COVID-19. Clinical Infectious Diseases, 2020.

29. Pal R, Bhadada SK. Should anti-diabetic medications be reconsidered amid COVID-19 pandemic? Diabetes research and clinical practice, 2020. 163. 
30. Koonin EV, Gorbalenya AE, Chumakov KM. Tentative identification of RNA-dependent RNA polymerases of dsRNA viruses and their relationship to positive strand RNA viral polymerases. FEBS Lett. 1989;252(1-2):42-6.

31. Gordon CJ, et al. The antiviral compound remdesivir potently inhibits RNA-dependent RNA polymerase from Middle East respiratory syndrome coronavirus. J Biol Chem. 2020;AC120:jbc. 013056.

32. Eastman RT, et al., Remdesivir: A Review of Its Discovery and Development Leading to Human Clinical Trials for Treatment of COVID-19. 2020.

33. Grein J, et al., Compassionate Use of Remdesivir for Patients with Severe Covid-19. New England Journal of Medicine, 2020.

34. Chen C, et al., Favipiravir versus Arbidol for COVID-19: A Randomized Clinical Trial. medRxiv, 2020: p. 2020.03.17.20037432.

35. Elfiky A, Ibrahim NS, Anti-SARS and anti-HCV drugs repurposing against the Papain-like protease of the newly emerged coronavirus (2019-nCoV). Research Square preprint, 2020.

36. Durdagi S, et al., Screening of Clinically Approved and Investigation Drugs as Potential Inhibitors of COVID-19 Main Protease: A Virtual Drug Repurposing Study. 2020.

37. Arya R, et al., Potential inhibitors against papain-like protease of novel coronavirus (SARS-CoV-2) from FDA approved drugs. 2020.

38. Talluri S. Virtual High Throughput Screening Based Prediction of Potential Drugs for COVID-19. 2020.

39. Claudio C. and F. Juan Di, In silico Drug Repurposing for COVID-19: Targeting SARS-CoV-2 Proteins through Docking and Quantum Mechanical Scoring. 2020.

40. Arya R, et al., Potential Inhibitors Against Papain-like Protease of Novel Coronavirus (COVID-19) from FDA Approved Drugs. 2020.

41. Elfiky AA, Ibrahim NS. Anti-SARS and Anti-HCV Drugs Repurposing Against the Papain-like Protease of the Newly Emerged Coronavirus (2019-nCoV). 2020.

\section{Figures}
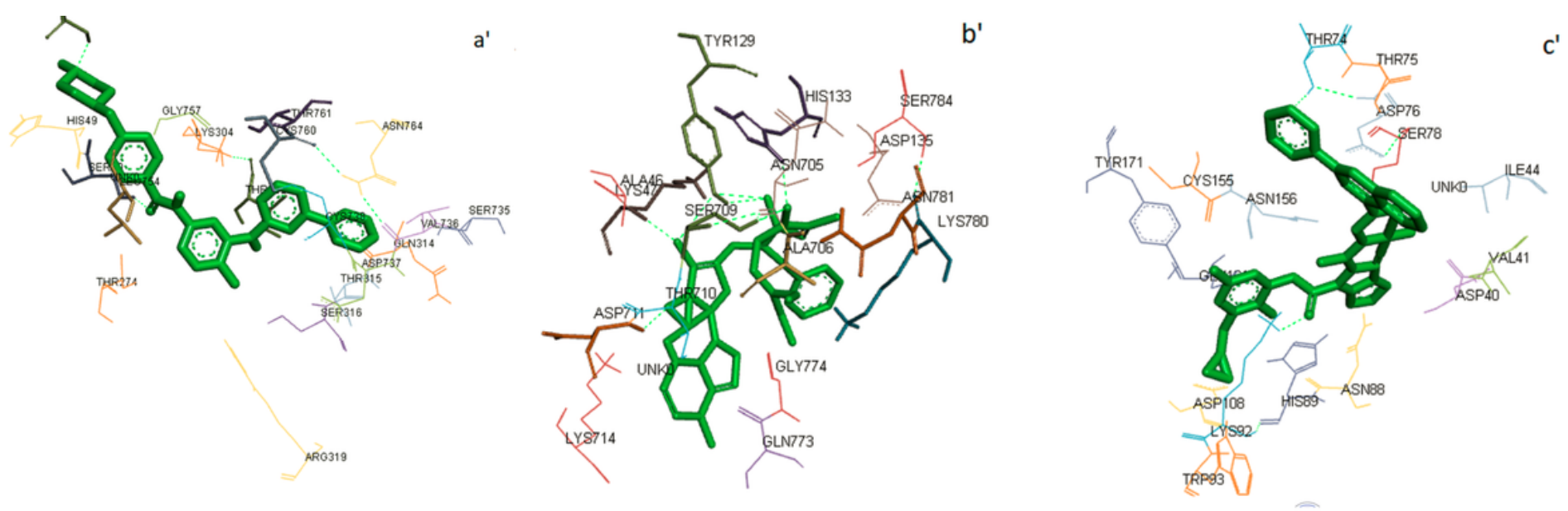
Figure 1

Visualization of docked poses of top 3 drug candidates with their protein target a. Binding interactions of Imatinib with active site residues of SARS-CoV-2 spike protein. a': 3D view of Imatinib with surrounding amino acids of 6XR8. b. Binding interactions of Remdesivir with active site residues of RdRP. b': 3D view of Remdesivir with surrounding amino acids of $6 \mathrm{M} 71$. c. Binding interactions of Telaprevir with active site residues of PLpro. c': 3D view of Telaprevir with surrounding amino acids of 6W9C.
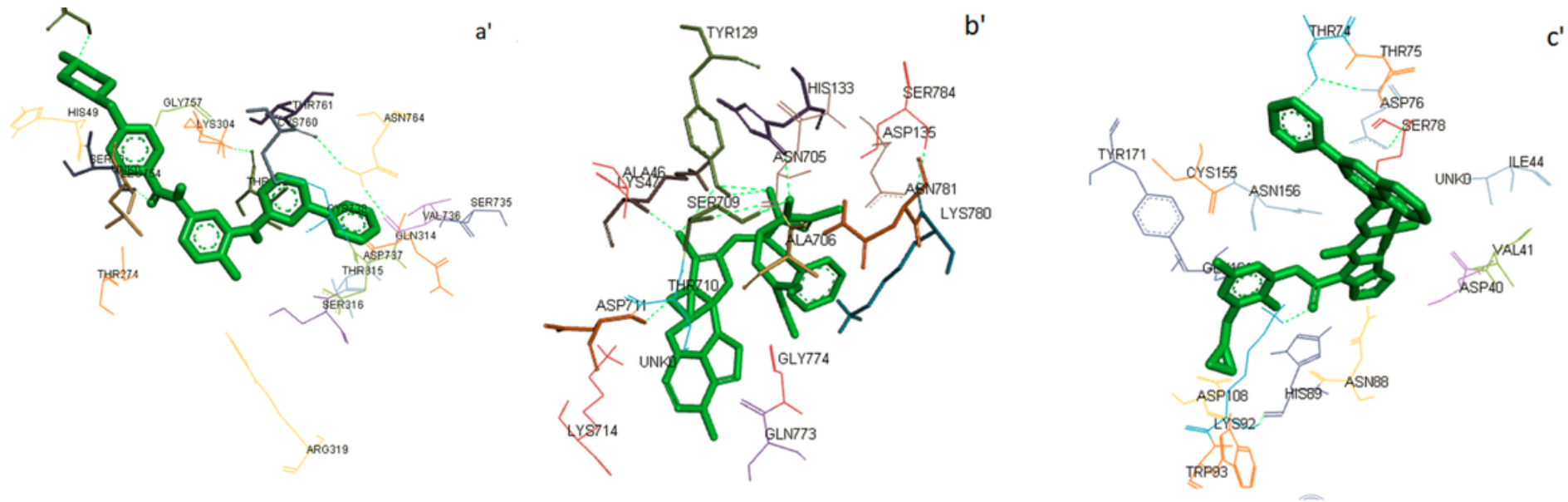

\section{Figure 1}

Visualization of docked poses of top 3 drug candidates with their protein target a. Binding interactions of Imatinib with active site residues of SARS-CoV-2 spike protein. a': 3D view of Imatinib with surrounding amino acids of 6XR8. b. Binding interactions of Remdesivir with active site residues of RdRP. b': 3D view of Remdesivir with surrounding amino acids of $6 \mathrm{M} 71$. c. Binding interactions of Telaprevir with active site residues of PLpro. c': 3D view of Telaprevir with surrounding amino acids of 6W9C. 